\title{
The Transnational Corporations' Activities and Their Impact on the Development of the Ukrainian Consumer Market: The Globalization Aspect
}

\author{
Tetiana Kniazieva, Hanna Radchenko, Anna Shevchenko
}

\begin{abstract}
The paper deals with the methodological principles of the dual education development in the hotel and restaurant business taking into account the modernization paradigm. The preconditions for the formation of dual education systems in different countries suggest that such an approach should be more appropriately applied to practically oriented specialties. Analysis of the advantages and disadvantages of existing dual education systems offers an opportunity to suggest ways to modernize them in the conditions of the information society development. The paper proposes a system of principles (general and specific) on which the cooperation of higher education institutions and hotel and restaurant business should be based. The stages and methodological approaches to the analysis of hotel and restaurant business modernization processes in the context of the formation of a dual education system are substantiated.
\end{abstract}

Keywords : concept, cooperative education, foundations, hospitality industry, system

\section{INTRODUCTION}

The influence of the process of transnationalization on the functioning of emerging consumer markets is an economy in a globalizing environment. The signs of globalization are evident in the growing openness of states, the liberalization of financial flows and national trade regimes, the formation of the world consumer and financial market, international economic institutions, the worldwide information network.

At the current stage of global economic relations, transnational corporations (TNC), along with subsystems of the world economy, regional groups, basing countries and recipient countries, are equated participants in international economic relations. Appearing as a leader in globalization, they have become systemic factors of global development, which have an increasing influence on the functioning of the world economy, specific economic actors.

The modern system of world order is such that the influence of TNCs on the evolution of national economies and

Revised Manuscript Received on November 15, 2019

* Correspondence Author

Tetiana Kniazieva, Doctor of Economic Sciences, Associate Professor,

International Economics Department, National Aviation University tatiana.kniazieva2017@gmail.com

Hanna Radchenko ,Candidate of Economic Sciences, Associate Professor, Marketing Department, National Aviation University annrad.01@gmail.com

Anna Shevchenko ,Candidate of Economic Sciences, Associate

Professor, Marketing Department, National Aviation University,

anna.v.shevchenko@gmail.com indispensable feature of the development of the global

the security of states has positive and negative consequences. They provide an increase in growth rates, the efficiency of production, the implementation of an investment regime, a qualitatively new level of security, which affects the degree of economic stability of countries, leveling their technological gap, changing the advanced technology on a global scale. At the same time, financial power allows

TNCs to oust national producers from the most profitable sectors of the economy, occupy significant segments of the consumer market, expand their own presence through imposed institutionalization, and act as a source of contradictions and negative socio-economic processes.

The urgency of the study is due to the fact that TNCs are a complex phenomenon that constantly evolves in the system of world economic relations, requiring the study of their essence, the identification of counteraction to the essential influence, the search tools, mechanisms of national and international control of the activities of transnational corporations in the emerging consumer markets.

Researchers studying the globalization of markets, monopolization, the export of capital and the process of transnationalization: Henry Dunning, Theodore Levitt, Evsey Domar, John Keynes, Karl Heinrich Marx, Fritz Machlup, John Stuart Mill, Gunnar Myrdal, Ragnar Nurkse, Bertil Ohlin, Michael Porter, David Ricardo, Adam Smith, Joseph Stiglitz, Sir Roy Forbes Harrod, Joseph Schumpeter and others.

In studies of economists of different times, the main focus is on the study of the theoretical foundation for the development of TNCs without taking into account the influence of contradictions and institutional contradictions associated with their functioning. The nature of the expansion of TNCs, the change in the profile of their activities, factors that determine these processes in the aspect of national specificity of countries, studied and presented in the literature is not enough.

The potentially possible positive and negative aspects of the impact of transnationalization on the Ukrainian consumer market as a subsystem of the world market are not fully covered, therefore, there is a need for theoretical studies that analyze its status and prospects of functioning.

Published By: 


\section{OBJECTIVES}

The purpose of the study is to identify trends, contradictions and peculiarities of the expansion of TNCs, the arguments for strengthening their influence on the Ukrainian consumer market, to determine the content blocks of the directions of its adaptation to the process of transnationalization, taking into account the target indicators of functioning, institutional aspects of regulation, priority areas of state protection, export-oriented activity and import substitution.

In accordance with this purpose, one can formulate the following research objectives:

- on the basis of the analysis of transnationalization, its essence and forms, to reveal the general laws of the expansion of transnational corporations, to substantiate it as an objective process of development and the factor of globalization;

- to determine the reasons, scale and directions of expansion of TNCs to emerging markets, taking into account the essence, dual nature and goals of functioning;

- to identify the main contradictions and trends in the introduction of TNCs in consumer markets in developing countries;

- to argue the significance of foreign economic expansion of TNCs as an objective factor of development, to evaluate their influence on the structure and dynamics of the consumer market of Ukraine as a subsystem of the world market.

The object of research is the modern TNCs, trends and indicators of their activities in the world consumer market.

\section{MATERIALS AND METHODS}

The methodology of the study includes the results of developments in the works of foreign scientists who studied the phenomenon of transnationalization of emerging markets as subsystems of the world market, the problem of the contradictory impact of the external economic expansion of TNCs in the consumer market in a globalized world.

In the process of solving the tasks, common scientific methods were used: dialectical, systemic-functional, structural-level, theoretical, monographic, and other scientific methods: logical, analytical, comparative, graphical and tabular interpretation of data.

The working hypothesis of the study is to assume that the consumer market of Ukraine, as a subsystem of the world market in terms of its openness, is objectively inclined to influence the process of transnationalization, which manifests itself in the contradictory, dualistic effect of TNCs, which determine the structural, volume and sectoral transformation of the market, reproduced in its quantitative and qualitative indicators, uneven functioning, which requires its balance on the basis of institutional regulation and improvement of the state defense system.

The degree of certainty and validity of scientific statements, conclusions and recommendations is confirmed by the generalization of the experience of TNC expansion into emerging markets, using modern methods of scientific analysis of world economic processes, testing in scientific discussions and the practice of transnationalization of the consumer market.

\section{RESULTS}

Modern TNCs are gigantic industrial and financial associations that are international in scope based on the principles of centralized planning and corporate governance on a global scale, implementing a policy in international trade aimed at expansion. TNCs are based on industrial and scientific-technical cooperation, technology exchange and capital investment, labor force migration, which deepen the process of internationalization, taking into account the objective tendencies of the international division of labor, and determine its new schemes.

The predominant way of international expansion of TNCs is through mergers and acquisitions through the purchase of controlling stakes. Monopolies in the form of the concern and TNCs in the way of establishing economic domination are the same type, and, therefore, there are no grounds in considering

TNCs as a new form of a monopolistic association. At the same time, uniformity does not mean their identity. TNC is a modified form of the concern, it has a number of specific characteristics.

Transnationalization is a process of quantitative and qualitative growth of TNCs, expansion and strengthening of their activities in the conditions of globalization. It is a rather controversial phenomenon, since the balance of positive and negative effects, shifts towards the last of them, in the technological, economic, political and social development of countries. The growing openness of the emerging economies, the internationalization of the functioning of national economic entities determines the definition as an independent sphere of theoretical analysis and practical knowledge of the influence of TNCs on the dynamics of the consumer market, which represents the organic interaction of the totality of institutions, elements and subjects of the process of commodity exchange.

An assessment of the causes, scales and tendencies of TNC expansion shows that under the conditions of globalization, the essence of monopoly capital does not change. TNCs expand the boundaries of their domination.

The expansion of transnational corporations not only enhances interaction with the state at the present stage of globalization, but also finds forms that most reflect the interests of transnational capital. Overcoming

the negative effects of transnational corporations on the domestic consumer market, ensuring the country's food security implies the implementation of a strategy of import substitution and reasonable protectionism, some of which are in contradiction with accepted international trade standards. It activates foreign economic policy, improves institutional and organizational and economic measures of state regulation to ensure the protection of the boundaries of the consumer market. From the standpoint of protecting the national consumer market and implementing the policy of import substitution, the main target benchmarks are defined: growth of own production; increase in consumer and investment demand; increasing non-raw exports through the export of high-tech, knowledge-based goods and services; intensification of measures within the system of integrated export support. 


\section{DISCUSSION}

Different categorical interpretations of globalization are presented in scientific publications, but the only common interpretation is absent. The most common is the understanding of the manifestations of the globalization of the economy through such processes as: increasing interdependence and the relationship of international economic relations, increasing their scale; the conventionality of borders between national economic relations and international ones; Inclusion in the global system of virtually all states. The category of «TNC» is based, first of all, on the wording of international organizations. Thus, UNCTAD, originally from TNCs, represented firms consisting of parent companies and their affiliates abroad, provided that the former controlled the activities of established affiliates whose shares were determined at a level not less than $10 \%$ in share capital.

As a consequence, UNCTAD identified new criteria for the inclusion of a firm in the category of TNCs, which resulted in clarification of the wording. Thus, TNC is a company with divisions in two or more countries, conducting a coherent policy with one or more decision-making centers. At the same time, the ability to control the assets of other economic entities in the countries of base, remains in the parent company, usually with the participation of capital. New branches and enterprises can be created overseas through direct investments, which turns the company into a transnational one. The lower limit of participation in capital is $10 \%$, which is defined as a sufficient condition for establishing control over the assets of subsidiaries. As a result, the number of TNCs increased by an order of magnitude in the global economy.

Among modern approaches to TNCs, Henry Dunning's Theory of Investment Development Path (IDP) is of particular importance. It argues that the level of economic development of countries is related to the degree of maturity of its enterprises, the volumes of participation in international flow of capital. In his theory, there are five levels of economic development of countries, which corresponds to the degree of evolution of TNCs, the relationship between exports and imports of foreign direct investment. They differ in the following points:

1. At the first level, the economies of the countries are poorly developed, not only there are no conditions for the accumulation and export of investments, but also their import, with the exception of those who possess significant reserves of natural resources.

2. At the second level, the economy of countries is characterized by a tendency of growing GDP - up to 2.5 thousand dollars per capita. Due to this expanding domestic demand in the consumer market. By attracting foreign TNCs who want to conquer foreign markets, imports of foreign direct investment are increasing. However, the level of development of national enterprises is still low, which does not contribute to the export of investments, and if it exists, it is oriented mainly to regional markets or countries with similar economic development.

3. In countries of the third level, 10 thousand dollars of GDP per capita is provided. Import of investments are slowing down against the backdrop of increased exports, as TNCs enter into tough competition with national companies, indicating the preconditions for the creation of the first national TNCs. However, as before, the amount

of accumulated investment with import is more than their export volumes.

4. At the fourth level - GDP is 10-36 thousand dollars per capita. The country demonstrates the growth of national TNCs, and exports exceed imports of foreign direct investment.

5. At the fifth level, according to some economists, is the US economy, which has the largest number of TNCs, and the volume of imports and exports of foreign direct investment is actually balanced.

Thus, this theory argues that the number of TNCs created in the country is a kind of indicator of the level of surplus investment in one or another field of production and the overall degree of economic development. By increasing the import of foreign direct investment, the effect of «swelling of investment demand» in various economic sectors is created, which stimulates the growth of national investment exports.

5.1. The regularity of foreign economic orientations in the process of transnationalization.

TNC means a large corporation that implements trade, investment, production-technological and integration ties with firms in two or more countries, which significantly affects the performance of a specific industry where TNC operates. It is assumed in some cases the need for their presence in no less than 6 countries.

Agreeing with this interpretation, it can be articulated that a transnational corporation is a form of development of monopoly capital. In this sense, it carries in itself all the features and contradictions of the monopolistic form of capital in general. However, it is obvious that it has a number of new features that in this form a monopoly has undergone a number of modifications, has found new features and characteristics.

Consequently, TNCs are peculiar not only with contradictions that are inherent in monopolistic capital in general, but also special, are generated by this form of association. The question of the interconnection of transnationalization, through the expansion of TNCs, and the deepening of the contradictions of modern capitalism, relate to a number of new relations in the global economy, the theoretical comprehension of a large part of which did not give unambiguous assessments in the literature. Part of these new ties and trends in the development of TNCs were not considered at all. Therefore, the specification of the theoretical and methodological position, which is the initial, basic for the analysis and conclusions regarding the transnationalization and deepening of the contradictions of capitalism in the conditions of globalization, becomes of special significance.

The essence of all forms of monopolistic unions is always the same - it is a conspiracy for the economic achievement of its dominant position. These forms differ according to the mechanism of economic realization of their monopoly position. In this sense, the conc ern differs from cartels, syndicates, trusts. Therefore, TNCs do not differ from the concern as a form of movement of monopoly capital. Having entered the international environment, TNCs do not lose any features of a concern in the form of a monopoly. Moreover, it broadens its reproduction on the path of transnationalization,

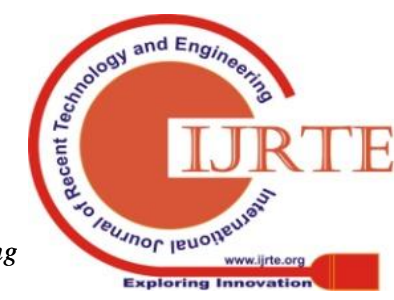




\section{Market: The Globalization Aspect}

using the mechanism of the concern - the «system of participation», which allows to establish financial control over huge capital.

Although the formation of TNC does not change the fundamentally universal connection in the system of modern capitalism, it nonetheless informs it of new elements, substantially modifying it. This is precisely what it means:

- there is a number of new qualities in the movement of corporate property;

- there are new qualities in the production and sale of additional value and profit;

- the scientific and technical base of the monopoly is growing sharply;

- TNCs generate new forms in the system of relations between monopolistic industrial associations and banks;

- the adaptive properties of the market system are sharply intensifying with the advent of TNC, its adaptation to the new conditions in the world, expanding the possibility of increasing the exploitation and looking for new forms.

There are differences and peculiarities between TNCs of different states in the intensity of expansion, its scale, due to differences in levels of concentration and centralization of capital in different countries. In particular, Western European monopolies inferior to the United States' in terms of concentration of production and capital, in terms of profit. Only by the degree of concentration employed in the largest enterprises they surpass them.

Thus, the clarification of the question of differences between TNCs is based on one of the most important principles of materialist dialectics - the principle of the relationship of general, special and individual. Relying on this principle allows us to conclude, firstly, that the only essential characteristic of TNCs is determined primarily by the socio-economic environment in which they are formed and operating and by the system of objective economic laws and regularities inherent to it (unevenness development, fierce competition and so on). Secondly, this approach allows us to conclude on a number of specifics of TNCs that are determined by the regional, sectoral specificity and country of origin.Contradictions of structural and functional character, crisis and conflict situations that deform and inhibit the processes of monopolistic capital accumulation, determine and support the high rates of the introduction of TNCs in emerging markets. An analysis of the sectoral, sectoral and structural transformation of emerging economies allowed to systematize a number of new trends in the expansion of TNCs (Table 1).

Thus, the analysis of the historical development of TNCs showed that the evolution of TNCs is closely linked with a sharp escalation of internal contradictions of capitalism at the end of the XX century. Their nature regarding expansion appears both on the national and international levels. All indicators in the statistical reporting of TNCs grow, (volume of FDI and retail sales, assets, profit, capitalization). An analysis of the trend of transnationalization shows the extent and directions of the expansion of TNCs into the consumer markets of developing countries, the distribution of natural, productive, financial and human resources, which suggests the formation of contradictions and new conflicts in the modern world economy (Fig. 1).

Their activities, the impact on the development and security of emerging economies are heterogeneous, has a dual meaning. On the one hand, TNCs are the main structure-creating link of the economy, the leading force in the country's development and the growth of production efficiency. On the other hand, they are the generator of a number of negative socio-economic processes. However, the general vector is that TNCs provide stable economic ties between different subsystems and countries, forming a single global economy. The trend of world development is characterized by increased concentration of production and capital, both at the micro level of enterprises, and on the mega-level of transnational corporations.

5.2. Features of functioning of the consumer market of Ukraine under the influence of foreign economic expansion of TNC.

The transnationalization of the Ukrainian consumer market is an objectively necessary and prepared strategic step for globalization, without which it would not be possible to form a developed economic system of the country, to ensure its competitiveness and efficiency. Systematization of trends and features of the functioning of the consumer market under the influence of foreign economic expansion of TNCs indicates the transformation of its volumes, structures and boundaries, as a complex mechanism for the interaction of social, economic, political, institutional elements and subjects of the process of commodity exchange (Table 2).

Monopolies at all times determined the direction and nature of state regulation at all times. With the development of transnational expansion, this trend has intensified. This is manifested in the following:

1) Within the framework of state-monopoly regulation of the economy, the strengthening of TNCs of its positions in the part of direct production and marketing of products through the penetration into the international environment is being carried out. It is about the almost complete fallout from the field of state control and regulation to $40 \%$ of the product produced at the branches of TNCs (referring to the transfer, intra-corporate movement of goods). States have lost the ability to directly control this part of TNC products.

2) In the closed, intra-corporate system of modern TNCs there is a huge flow of mutual supplies of intermediate products and services. The zone of monopolistic production is increasing, which is not achievable for state regulation. Obviously, these flows of goods and services are least vulnerable to the impact of market forces protected from the effects of competition on contracts and supply agreements.

3) The positions of many TNCs have substantially strengthened due to the ability to transfer part of their production, especially from industries that are experiencing the most severe blows to the structural crisis, to other countries - to less developed countries and to developing countries.

4) Due to the asynchronous nature of crisis processes in different countries, TNCs can relocate capital to those regions where production and economic processes are in a state of recovery. Even without such a transfer, due to the distribution of capital, TNCs can compensate for the loss from business

activity by expanding their production in branches located in other countries.

5) With the expansion of the TNCs, they were able to choose among the sources of external financing those that are most in their interests, to receive funds in the international market of loan capital.

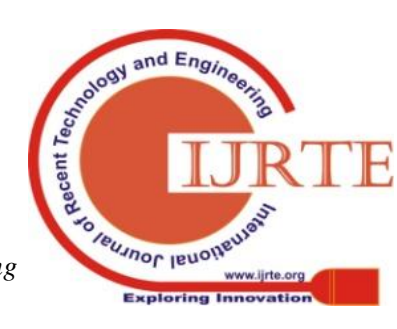


6) Strengthening the position of transnational capital as a self-regulated system under the conditions of globalization consists in the relative reduction of the possibility of influence (economic and legal) on the branches of their national concerns.

7) The system of economic means of effective control is developed, which includes: technological and financial dependence of branches from the parent company; a closed system of production and marketing of products.

For modern conditions, the characteristic is not the strengthening of the regulatory role of the state of the activity of TNCs, but its stimulation. The story of a rather deep retrospective does not know practically the cases of death of giants of international business as a result of deliberate actions of any state. TNCs have identified the parameters, vectors and trends of development: the needs and tastes of consumers; models of consumer behavior and motivation; advantages and standards, unifying them; volume and structure of demand; capacity of the market and its business environment; production structure; the volume and composition of the product offer; infrastructure of the market (trade networks, logistics, systems of after-sales service); system of marketing, management, target and priority groups of the range of commodity products, etc.

The expansion of TNCs in the consumer market has passed 3 stages, which result was the presence of the largest TNCs in Ukraine: electronic and electrical engineering, chemistry, food and food industry, pharmaceuticals, trade and services.

In 2018, net foreign direct investment inflow to Ukraine amounted to 2.4 billion dollars, which is $7.7 \%$ less than in 2017. Thus, in 2018, the volume of direct foreign investments in Ukraine decreased by 200 million dollars. More than half of direct foreign investments $-58 \%$ or 1.4 billion dollars were sent to the real sector of the economy (National Bank of Ukraine: official website).

For the last eight years (2011-2018), the peak investment in Ukraine of foreign investment fell in 2011, when the infusion into the economy amounted to more than 6 billion dollars. Over

the past four years, the size of the investment in

Ukraine has not come close to this mark. The logical drop in the number of foreign investments took place in 2014, when the military conflict in the Donbass began, and the political situation in the country was extremely unstable. Then the Ukrainian economy received only 2.5 billion dollars 55\% less than in 2013 (National Bank of Ukraine: official website). However, already in 2014, the volume of investments amounted to 3.8 billion dollars - twice as much as a year earlier. The inflow of foreign investments slightly increased in 2016 (National Bank of Ukraine: official website) (Fig. 2).

Over the past two years, foreign investors have invested the most in financial and insurance activities, as well as wholesale and retail trade, repair of motor vehicles. This year investments came in the sphere of scientific and technical activity. Russia, as it does not seem strange, has invested in the Ukrainian economy the most money, in 2018 its investments amounted to $34.6 \%$ of the total volume. The funds are also invested by Cyprus, the Netherlands, Austria, Poland, Great Britain, France, Germany, Italy and Hungary (Fig. 2).
Since the beginning of the XXI century, the development of the retail market has developed, changes in the structure of demand in favor of non-food products, paid services, the growth of organized trade and turnover of catering enterprises. During the period of 2011-2018, the volume of retail trad

turnoverincreased by 3.12 times, while the turnover of catering enterprises was 2.5 times. At the same time, the share of imported products in retail commodity turnover varies by an estimated $40-60 \%$. The attractiveness of the Ukrainian market for TNCs has led to the fact that by the year 2018 about $75 \%$ of imported goods (footwear, clothes, household appliances, etc.) are sold in the non-food segment, and their own production is $25 \%$ (State Statistics Service of Ukraine: official website).

The strategic interests of TNCs covered such segments of the consumer market as «Food and Beverages», «Retail Business», «Agriculture (agribusiness)», where local companies were located (Table 3 ).

The unevenness of Ukraine's economic development under the influence of TNCs as a whole, and of the consumer market in particular, manifested itself in industrial, sectoral and structural transformation; spin-off development in a regional context; the formation of a competitive environment, inadequate status and capabilities of the domestic commodity producer; the scales of expansion and unification achieved through mergers and acquisitions (Table 4).

The analysis of the practical activities of TNCs allows us to identify the main and secondary factors that contribute to identifying conditions for overcoming unevenness, structural distortions and attracting foreign companies to the country, taking into account national interests.

The main prerequisites for the development of this process on the Ukrainian consumer market and the economy as a whole are:

- favorable macroeconomic situation (GDP growth, inflation reduction);

- low costs in production and in the market;

- a large, roomy domestic market, which is very relevant in connection with the need to minimize transaction costs;

- favorable investment climate for the import of equipment and goods required for TNCs activities;

- sufficient stability of the country's economy to global economic and financial crises;

- political stability and reduction of the country's risks;

- availability of skilled labor resources, and willingness to work in subsidiary structures of TNCs;

- availability of natural resources for sectors focused on extraction and their production processing;

- increase in incomes and intensive development of consumer lending;

- qualitative updating of the assortment of the consumer market;

- presence of a leading role of the country in the region.

The market for Merging \& Acquisition ( $M \& A)$ in Ukraine is growing again today. In 2017, the number of transactions increased by $22 \%$ to 67 . And their total volume increased to

1 billion dollars, or $37 \%$ at once (State Statistics Service of Ukraine: official website).

However, while the activity of transactions is still much lower than in 2013, and the

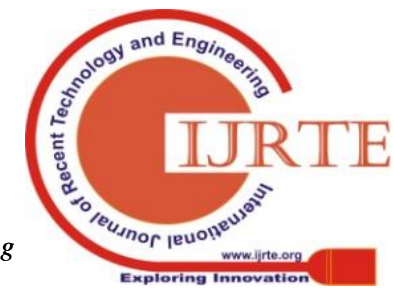


volume still does not reach even $1 \%$ of Ukraine's GDP. While in other countries it is about 3-4\% of GDP.

The Ukrainian M \& A market is four times lower than the world average, and less than one-tenth of the US or UK market, and much more modest compared to other countries in Central and Eastern Europe. For example, the volume of mergers and acquisitions in the world since the beginning of 2018 has already reached 1 trillion dollars. According to the Financial Times, it is the fastest growth in history.

The volume of M \& A market in Ukraine in 2018 has almost doubled. Thus, for the year, $80 \mathrm{M} \& \mathrm{~A}$ deals totaled 1.82 billion dollars. Compared to 2017, the total amount of transactions increased by $78 \%$, and their number - by $19 \%$ (State Statistics Service of Ukraine: official website).

However, the volume and number of transactions are still far from pre-crisis data for 2013, when 108 transactions were fixed at 3.82 billion dollars (National Bank of Ukraine: official website). The increase is due to the restoration of the Ukrainian economy, as evidenced by international research: Moody's rating agency has increased its sovereign debt rating three times over the past three years, Ukraine has improved its position in the World Bank's Doing Business and Global Index of

Competitiveness. In addition, public sector reform was approved in 2018 by the International Monetary Fund.

The most dynamic this year is the IT-sector. The most active areas for M \& A in 2019: Information Technology (IT); food and agriculture (agribusiness); renewable energy; power generating and power distribution companies; light industry; transport and infrastructure; pharmaceutical industry; e-commerce.

Analyzing the above trends, one can determine that the main driver of the $\mathrm{M} \& \mathrm{~A}$ market in Ukraine will be:

the stability of the macroeconomic policy of the NBU, the ministry of finance, the government, and the effective management of public debt. An important result of this policy for $\mathrm{M} \& \mathrm{~A}$ growth is the projected exchange rate and inflation;

implementation of the IMF financial support program; reforming the judicial system and judicial practice to protect foreign investors and minority owners;

demonstration of progress in the fight against corruption;

realization of export opportunities of a free trade agreement between Ukraine and the EU, which provides the potential for growth of the Ukrainian agro-business business, first of all.

The expansion of TNC, on the one hand, has had a positive impact on consumer preferences and foreign economic activity of enterprises: the pace of «innovative economy»; the emergence of new products and industries (40-60\% of turnover of successful companies is due to the goods introduced to the market in the last 5-7 years); use of information technology and e-commerce; reduction in the cost of communications; development of network organizations; eliminating trade barriers; the importance of international and individual marketing. On the other hand, losses are borne by domestic commodity producers, since the activities of TNCs are aimed at improving their own financial state (growth of production, capitalization of profits), asset growth, further expansion. Therefore, the strategic direction of development of Ukrainian companies should be: concentration and diversification of production activities on the basis of product and geography, expansion of the range of products, continuous development of new products and innovative technologies, taking into account the priorities of the national producer and consumer, the formation of stable market boundaries and the efficiency of its functioning.

\subsection{Adaptation of the Ukrainian consumer market to} the process of transnationalization.

Built in global commodity flows, the consumer market is experiencing structural transformations under the influence of TNCs, geopolitical changes, the regrouping of forces between dominant countries and regional associations. Its functioning and growth rates were influenced by the diverse dynamics of the largest economies and the world market - the crisis processes in developed countries in 2013-2017; the trend of a decrease in world prices and value of trade, due to aggravation of the geopolitical situation and the situation of raw commodity markets; institutional barriers in EU countries.

The consumer market has lost its leading position, characterized by diminished volumes and changes in the structure of retail trade, deterioration in the quality and range of products and services offered, the withdrawal of a number of manufacturers, well-known brands, drop in profits and profitability of trade organizations. Increasing competition and monopolization in the retail market under the influence of the escalation of trading networks that have large-scale resources and pushed the weak business players.

Global megatrends testify to the destructive entry of the Ukrainian consumer market into the global market. TNCs have transformed the sectoral structure of production and the market, changing the flow of goods from the country. The analysis of indicators of commodity turnover, its dynamics and volumes, structure of export and import confirm the narrow specialization of the country in the system of international division of labor, export-oriented orientation of foreign economic activity.

In 2018, exports of goods from Ukraine amounted to 26 billion 876.2 million dollars, or $112.7 \%$ compared to 2017 . And imports to Ukraine amounted to 30 billion 939.9 million dollars, or $115.9 \%$ compared with 2017 (State Statistics Service of Ukraine: official website).

Ukraine is trading with 212 countries of the world. Despite the annexation of the Crimea and the war on the Donbass, the level of export of goods from Ukraine to the Russian Federation amounted to $8 \%$ of the total trade of our country, amounting to 2 billion 147.9 million dollars. In turn, Ukraine, in a state of «hybrid war» with the Russian Federation, in January-July 2018 imported from Russia goods and services worth 4 billion 439 million dollars, which was $14.3 \%$ of the total trade (State Statistics Service of Ukraine: official website).

The second partner in terms of trade with Ukraine is Poland, where exports amounted to $7.1 \%$ or 1,897 million dollars. The import of Polish goods to Ukraine is $14.3 \%$ (2033.2 million dollars). Italy in the international activity with Ukraine occupies the third place from which imports into Ukraine in 2018 amounted to 1 billion 085.7 million dollars, or $3.5 \%$ of the total volume, while exports from Ukraine to Italy - 1650.2 million dollars, that is equal to $6,1 \%$ (State Statistics Service of Ukraine: official website).

The main goods that are exported from Ukraine to other countries in 2018 were: 
non-precious metals: including ferrous metals, $23.1 \%$ of exports or 6 billion 199.2 million dollars;

products of vegetable origin - in the amount of 4772.8 million dollars, or $17.8 \%$ of exports: including grain crops (in the amount of 3 billion 573.2 million dollars, or $13.3 \%$ of exports);

machinery, equipment and machinery $10.1 \%$ of exports, which is 2 billion 709.9 million dollars;

ready-made food products: in 2018 Ukraine exported products worth 1 billion 687 million dollars $-6.9 \%$ of total exports;

fats and oils of animal or vegetable origin: the total amount of exports amounted to 2 billion 652.8 million dollars, which is equal to $9.9 \%$ of total exports (State Statistics Service of Ukraine: official website).

The main import article in 2019 is fuel and oil products imported by Ukraine to 7 billion 3.9 million dollars (22.6\% of total imports).

In addition, the main articles of import to Ukraine in 2018 were:

industrial machinery, equipment and machinery. The amount of such imports to Ukraine amounted to 6 billion 267.9 million dollars (20.3\% of total imports), including only imports of equipment for nuclear reactors amounted to 3 billion 589.9 million, or $11.6 \%$ of total import;

production of chemical and related industries: $13.4 \%$ of the total amount or 4 billion 134.2 million dollars; the import of land transport vehicles, aircraft and vessels - this is still $8.0 \%$ of imports or 2 billion 465.6 million dollars;

cars and other land transport $-7.6 \%$ of the total amount, equal to 2 billion 336 million dollars.

Thus, much of what is exported from our country is raw materials and goods with low added value.

Expansion of TNCs without government intervention leads to unstable functioning of the consumer market, loss of state sovereignty. The index of food imports exceeds the permissible values of the country's economic security. The share of foreign capital in the food industry is $60 \%$ and continues to grow. The country does not provide itself with products of its own production. For the development of the economy taking into account internal interests, it is necessary: activation of the introduction of TNCs, operating in the sphere of manufacturing industry; creation of joint research enterprises with participation of them, for development and reception of the newest technologies and goods; a reorientation to restructuring and modernization of industries with a long payback period (e.g., machine building), due to the unevenness of investments by industries; the expansion of agricultural co-operation in the country as an instrument for protecting farmers from the expansion of TNCs; development of own domestic brand.

The main target of Ukraine is protection of the consumer market by increasing non-raw exports, increasing volumes of supply of products of a higher degree of processing, technically and technologically complex, which involves the development and implementation of a system of organizational and economic measures of state foreign economic regulation (Fig. 4).

It is necessary to create positive domestic conditions: stable GDP growth (2-3\%, without forced increase due to new technologies of the energy complex); to increase the competitiveness of industry; to expand investment and consumer demand; to increase export potential in the field of services; to stimulate the development of a set of measures to support export and intensify import substitution; to support domestic producers of agricultural products and light industry; review monetary policy; to improve price, tariff regulation.

To this end, the practice of creating state-owned corporations that can compete with foreign $\mathrm{TNCs}$, for example, is a specialized state corporation in the field of agro-industrial complex. Thanks to such an institute it is possible to ensure the development of «adjacent clusters», factories for the production of agricultural machinery, fertilizers, etc. The chain will develop production clusters, necessary for the functioning of related branches of the second level. In the long-term, the economy can be rebuilt on the innovative-technological type.

\section{CONClusion}

On the basis of the analysis of indicators of Ukraine's activity on the world market and the impact on the economy of the expansion of TNCs, a number of conclusions can be drawn. Transnationalization is the process of quantitative and qualitative growth of TNCs, expansion and strengthening of their activities in the conditions of globalization. This is a controversial phenomenon, since the balance of positive and negative effects is shifted towards the last of them in the technological, economic, political and social development of countries. Openness of the emerging economies, the internationalization of the functioning of national economic entities, and the deepening of the international division of labor, triggers an increase in the influence of TNCs on the dynamics of the consumer market, which represents an organic interaction of the totality of institutions, elements and subjects of the process of commodity exchange.

Increasing presence, massive invasion of international business and national markets, as well as all processes in the global economy, are controversial and dual. On the one hand, the expansion of TNCs provides external impulses and incentives for production in host countries, contributes to the deepening of the division of labor, specialization and co-operation. On the other hand, the inevitability of the emergence of numerous negative consequences, due to the monopolistic form of these processes. Further, on the one hand, external expansion contributes to the emergence of large international complexes, the functioning of integrated production systems, but, on the other hand, the monopolistic form of their organization ensures the creation of a holistic system of corporate dominance in the global economy. The largest number of TNCs are owned by the developed countries. This points to an internal investment over-accumulation, a surplus of capital flows that go beyond national economies.

Ukrainian realities show that under the conditions of globalization the essence of monopoly capital does not change, it finds a new form of existence through transnationalization. Large monopolies, expanding the boundaries of their domination, turn into TNCs.

The general vector and direction of evolution is that TNCs provide stable economic ties between different subsystems and countries, in this connection the integration of national economies into a single world economy takes place. The trend of world development is

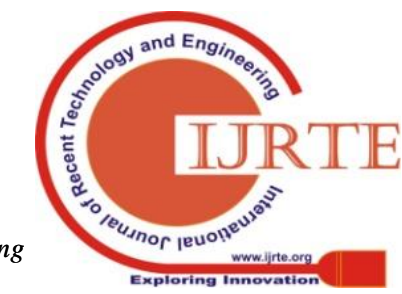




\section{Market: The Globalization Aspect}

characterized by increased concentration of production and capital, both at

the micro level of enterprises, and on the mega-level of transnational corporations.

Expansionist activity of TNCs in the Ukrainian consumer market is complex and controversial. In general, they have a positive impact on the development of the economy, but are focused on improving their own financial state (increase production, capitalization of profits) and further development of the company. Therefore, without government intervention, the expansion of TNCs leads to the loss of state sovereignty, which undermines national security of the country.

\section{RECOMMENDATIONS.}

TNCs have transformed the sectoral structure of the market and production, changing the flow of goods from Ukraine, which is determined by its place in modern international division of labor and specialization of production. The unevenness of the development of the consumer market under the influence of TNCs manifests itself in regional, structural, sectoral transformations, changes in the competitive environment, through the gradual buildup of capital and assets, reunion, achieved through mergers and acquisitions.

The Ukrainian consumer sector, retail trade and agriculture have undergone active transformation processes. Therefore, a set of state measures in the field of industrial and structural policies aimed at accelerating the growth of domestic production, the formation of stable boundaries of the Ukrainian consumer

\section{REFERENCES}

1. Arrow KJ 1973. Higher education as a filter. Journal of Public Economics, 2(3). 193-216.

2. Castells M 1997. The End of the Millennium, The Information Age: Economy, Society and Culture. Cambridge, MA; Oxford, UK: Blackwell.

3. Eames C, Cates C 2011. Theories of learning in cooperative and work-integrated education. International handbook for cooperative and work-integrated education: International perspectives of theory, research and practice. 2. 41-52.

4. Fässler J 2018. Implementing the dual education system: the success, the challenges and the future. From <https://www.alpla.com/en/blog/2018/03/implementing-dual-educati on-system-success-challenges-and-future> (Retrieved on 1 July 2019).

5. Göhringer A 2002. University of Cooperative Education - Karlsruhe: The Dual System of Higher Education in Germany. Asia-Pacific Journal of Cooperative Education, 3(2). 53-58.

6. Holod A 2017. Bezpeka rehional'nykh turystychnykh system: teoriya, metodolohiya ta problemy harantuvannya [Safety and Security of Regional Tourism Systems: Theory, Methodology, and Guarantee Problems]. Lviv: LSUPC.

7. Layard R, Psacharopoulos G 1974. The Screening Hypothesis and the Returns to Education. Journal of Political Economy, 82. 985-998.

8. Schultz TW 1960. Capital Formation by Education. Journal of Political Economy, 6. 571-583.

9. Sen A 1990. Development as Capability Expansion. Human Development and the International Development Strategy for the 1990s. London: Macmillan, pp. 41-58.

10. Shevchuk A 2013. Rehional'ni osvitni systemy: teoriya, metodolohiya, praktyka innovatsiynoho rozvytku [Regional Educational Systems: Theory, Methodology, Practice of Innovative Development]. Lviv: Institute for Regional Studies of the NAS of Ukraine.

11. Van der Vorm PT 1988. Response to the Preliminary Report of the Ad Hoc Committee on Cooperative Education. Journal of Cooperative Education, 24(2-3). 120-124.

\section{AUTHORS PROFILE}

Tetiana Kniazieva, Doctor of Economic Sciences, Associate Professor, International Economics Department, National Aviation University $\underline{\text { tatiana.kniazieva2017@gmail.com }}$

Hanna Radchenko ,Candidate of Economic Sciences, Associate Professor, Marketing Department, National Aviation University annrad.01@gmail.com

Anna Shevchenko ,Candidate of Economic Sciences, Associate Professor, Marketing Department, National Aviation University, anna.v.shevchenko@gmail.com 